\title{
Drug-drug Interactions of Statins Potentially Leading to Muscle-Related Side Effects in Hospitalized Patients
}

\author{
CAMELIA BUCSA ${ }^{1}$, ANDREEA FARCAS $^{1}$, D. LEUCUTA ${ }^{2}$, CRISTINA MOGOSAN $^{1}$, M. BOJITA ${ }^{1}$, D.L. DUMITRASCU ${ }^{3}$ \\ ${ }^{1}$ Drug Information Research Center, "Iuliu Hatieganu" University of Medicine and Pharmacy, Cluj-Napoca, Romania \\ ${ }^{2}$ Department of Medical Informatics and Biostatistics, "Iuliu Hatieganu" University of Medicine and Pharmacy, Cluj-Napoca, Romania \\ ${ }^{3} 2^{\text {nd }}$ Medical Department, "Iuliu Hatieganu" University of Medicine and Pharmacy, Cluj-Napoca, Romania
}

\begin{abstract}
Introduction. The associations of drugs that may interact with the statins resulting in elevated serum concentration of the statins are an important risk factor for statin induced muscle disorders. We aimed to determine the prevalence of these associations in all hospitalized patients that had been prescribed statins before/during hospitalization and to find out how often they are associated with muscle-related side effects.

Methods. This prospective, non-interventional study performed in two internal medicine departments included patients with statin therapy before/during hospitalization. Data on each patient demographic characteristics, co-morbidities and treatment was collected from medical charts and interviews. We evaluated patients' therapy for the targeted associations using Thomson Micromedex Drug Interactions checker and we ranked the identified drug-drug interactions (DDIs) accordingly. Each patient with statin treatment before admission was additionally interviewed in order to identify muscular symptoms.

Results. In 109 patients on statin treatment we found 35 potential (p) DDIs of statins in 30 $(27.5 \%)$ patients, most of which were in the therapy before admission (27 pDDIs). The pDDIs were moderate (20 pDDIs) and major (15 pDDIs). Of the total number of pDDIs, 24 were targeting the muscular system. The drugs most frequently involved in the statins' pDDIs were amiodarone and fenofibrate. Two of the patients with pDDIs reported muscle pain, both having additional risk factors for statin induced muscular effects.

Conclusion. The prevalence of statins' pDDIs was high in our study, mostly in the therapy before admission, with only a small number of pDDIs resulting in clinical outcome.
\end{abstract}

Key words: drug interactions, statins, myalgia.

\section{INTRODUCTION}

In the past 2 decades, the utilization of statins for their cholesterol-lowering and pleiotropic effects has increased considerably. Following their increased utilization, controversies arose on their prescription patterns due to safety concerns [1-7]. Common adverse effects of statins include dyspepsia, flatulence, constipation, generalized gastrointestinal discomfort, elevated transaminase levels, myalgia, headache, sleep disorders and central nervous system disturbances [8]. The main safety concerns related to the use of statins are the muscle-related side effects of variable intensity. The mild and moderate myopathies (e.g. myalgia, limb weakness) are relatively common among statin users [9], the numbers ranging from $1 \%$ to $5 \%$ of patients in the statin groups and placebo groups alike in randomized controlled trials of statin efficacy $[8,10]$. In observational real-life studies the rate is up to $10 \%$ [9]. The rhabdomyolysis (muscle symptoms associated with a creatine kinase [CK] level 10 times the upper limit of normal or higher) is the most severe statin-induced muscle disorder, with a rare frequency $(0.1-0.6 \%)[11,12]$.

The risk factors associated with statininduced myopathy include a history of muscle symptoms or elevated CK, hypothyroidism, female sex, older age, renal and hepatic insufficiency, diabetes, excessive alcohol consumption, and concomitant use of drugs that increase the serum concentration of statins [13-16].

As statins (except pravastatin and rosuvastatin) undergo the CYP3A4 metabolism [17], coadministration with drugs that are either CYP3A4 substrates or inhibitors increases the bioavailability of the statins (simvastatin, lovastatin, atorvastatin and to a lesser extent fluvastatin) by inhibiting the hepatic first-pass metabolism [18]. The concomitant therapy with CYP3A4 substrates/inhibitors was found in up to $30 \%$ of the patients prescribed with CYP3A4 metabolized statins in a study performed in the United Kingdom [19]. Moreover, approximately $4 \%$ of the patients on statin therapy reporting muscle pain in a US survey used medication that inhibits the CYP3A4 [20]. 
Some of the inhibitors and substrates of CYP3A4 (e.g. clarithromycin, erythromycin, cyclosporine) may also inhibit the organic anion transporting polypeptide 1B1 (OATP 1B1) and some (e.g. amiodarone, ticagrelor, fluvoxamine) may inhibit the P-glycoprotein (P-gp) leading to an increased systemic exposure to the statin and subsequently to an increased risk of myopathy.

Fibrates are another drug class that can induce muscular disorders, so their association with statins increases the risk for developing such disturbances by additive mechanism [21].

As the incidence of statin-induced myopathy was reported higher in real-world patients [22], we chose to study statins' drug-drug interactions (DDIs) that may lead to muscle-related side effects in hospitalized patients in a non-interventional prospective manner.

\section{Objectives}

The main purpose of our study was to determine the prevalence of statins' potential DDIs (pDDIs) in all hospitalized patients that had been prescribed statins before/during hospitalization. Secondly, we aimed to find out how often these pDDIs result in muscular effects.

\section{MATERIAL AND METHODS}

\section{Study design and patients}

We conducted a prospective, non-interventional study in two internal medicine departments with a total bed capacity of 100 patients, for 8 weeks (November 2014 - January 2015). We included all patients whose medical charts were available for review on every Tuesday of the study weeks and had a documented statin treatment before or during hospitalization (up to that date) for the analysis of pDDIs. DDIs with clinical outcome were analyzed in patients with statin treatment before hospitallization. All statins on the market in 2014 in our country were included in the study (atorvastatin, fluvastatin, rosuvastatin, pravastatin, lovastatin and simvastatin).

The study protocol was approved by the University of Medicine and Pharmacy Cluj-Napoca Ethics Committee.

\section{Study protocol and data collection}

Information on patients' demographics, medical history, diagnosis and symptoms at admission, medicines used 1 month before admission and during hospitalization (start and end dates, doses), and relevant laboratory tests results (CK, hepatic transaminases, creatinine and urea) was collected through chart review.

In addition, we interviewed all patients that had been prescribed statins, either before admission or during hospitalization. The information gathered during the interview included the list of prescription drugs and self-medication before admission (for confirmation of the data from the charts). In addition to structured questions, questions such as "Did you suffer from some disease during this period?" or "Did you actually take the medicine X (documented in the chart)?" were added to help the patient recall the medicines taken. If available, we also evaluated all of the medication containers to check for consistency with the self-reported data.

Each patient with statin in the therapy before admission was also interviewed for muscular symptoms (localization, type of pain, severity, time of onset in relation to the pDDI, if the case).

We defined a pDDI as the concomitant use (defined as one or more days of overlap in use) of a statin and another medicine (CYP3A4 inhibitor or not) with the potential of affecting the toxicity of one or both medicines. After identifying all the medicines used concomitantly prior/during hospitallization, pDDIs were identified using the Thomson Micromedex program [23] and ranked accordingly, as contraindicated associations, major, moderate or minor pDDIs.

\section{Statistical analysis}

All collected data regarding patients' characterristics, diagnoses, medications and the DDIs detected were analyzed with descriptive statistics. Quantitative data was presented by mean and $95 \%$ confidence interval (for normally distributed data), and by median and interquartile ranges (for not normally distributed data). Quantitative data not following the normal distribution was compared using the Mann Whitney U test. For all tests the level of significance used was 0.05 , and the two tail p-value was computed. Statistical analysis was performed in R environment for statistical computing and graphics, version 3.2.0 [24].

\section{RESULTS}

\section{Patients' characteristics and prescribed drugs}

During the 8 weeks period, we reviewed the charts of 521 patients. Of these, 109 patients were on statin therapy, $86(79 \%)$ being prescribed statin before admission and 40 (37\%) during hospitallization (continuing to use the statins prescribed 
before admission or newly prescribed during hospitalization). The mean age of our patients was 66.6 years and most of them were males $(52 \%)$. The median length of hospital stay was 7 days, ranging from 3 to 36 days. Patients' characteristics are presented in Table 1.
The medium number of diagnostics/patient was 5.3, with cardiovascular diseases being the most frequent (in approximately $95 \%$ of the patients). The median number of prescribed drugs/patient was 6 (range 0-13) before admission and 5 (range 0-15) during hospitalization (Table 1).

Table 1

Patients' characteristics

\begin{tabular}{|c|c|c|}
\hline Characteristic $(n=109)$ & & \\
\hline Sex, no. $(\%)$ & Female & $52(48)$ \\
\hline Age, Years & Mean $(95 \% \mathrm{CI})$ & $66.6(64.65-6.51)$ \\
\hline Elderly patients, no. (\%) & $\geq 65$ years & $57(52)$ \\
\hline Hospital stay, Days & Median (IQR) & $7(5-9)$ \\
\hline Alcohol consumption, no. (\%) & Yes & $17(16)$ \\
\hline Smoking habits, no. (\%) & Yes & $28(26)$ \\
\hline Patient co-morbidities, no. (\%) & Cardiovascular & $103(94)$ \\
\hline & Metabolic and endocrine & $87(80)$ \\
\hline & Gastrointestinal & $41(38)$ \\
\hline & Renal & $37(34)$ \\
\hline & Hepatic & $51(47)$ \\
\hline & Respiratory & $25(23)$ \\
\hline & Musculoskeletal & $48(44)$ \\
\hline & Psychiatric and neurological & $31(28)$ \\
\hline & Ophthalmologic & $12(11)$ \\
\hline & Dermatologic & $7(6)$ \\
\hline & Cancer & $17(16)$ \\
\hline No. of drugs/patient before admission, no. (\%) & 0 drugs & $14(13)$ \\
\hline & $1-5$ drugs & $23(21)$ \\
\hline & 6-10 drugs & $66(61)$ \\
\hline & $\geq 10$ drugs & $6(5)$ \\
\hline No. of drugs/patient during hospitalization, no. (\%) & 0 drugs & $29(27)$ \\
\hline & $1-5$ drugs & $17(16)$ \\
\hline & 6-10 drugs & $50(47)$ \\
\hline & $\geq 10$ drugs & $11(10)$ \\
\hline Patients on self medication, no. (\%) & & $6(5)$ \\
\hline
\end{tabular}

$\mathrm{n}=$ number of patients in a given category; $\mathrm{SD}=$ standard deviation; $\mathrm{CI}=$ confidence interval; IQR $=$ interquartile range

The most prescribed statin was atorvastatin (52 patients), followed by rosuvastatin (41 patients), simvastatin (15 patients) and lovastatin in only 1 patient. Cholesterol values were in the same range for both patients with/without pDDIs (medium value of 187 vs 189). Serum creatinine, urea and gamma glutamyl transferase were significantly higher in patients with pDDIs $(\mathrm{p}=0.01, \mathrm{p}=0.005$ and $p=0.04$, respectively). Other laboratory values of the patients with/without pDDIs are included in Table 2 .

\section{Potential DDIs}

In the therapy of the 109 patients, we found 35 pDDIs of statins in $30(27 \%)$ patients. Most of the pDDIs were found in the therapy before admission (27 pDDIs). With regard to the severity, as ranked in Micromedex Drug Interaction checker [23], most of the pDDIs were moderate (14 pDDIs in the therapy before admission and 6 during hospitalization), followed by major (13 pDDIs before admission and 2 during hospitalization), and no contraindicated associations or minor pDDIs (Table 2).

The possible outcome of majority of the pDDIs was targeting the muscular system. Of the total number of pDDIs, 24 (corresponding to 21 patients [19\%]) could have affected the muscular system, increasing the risk of muscular disorders.

The drugs most frequently involved in statins' pDDIs were amiodarone (6 pDDIs before admission/4 pDDIs during hospitalization) and fenofibrate (5 pDDIs before admission/1 pDDI during hospitalization).

We identified $12 \mathrm{pDDIs}$ (corresponding to 7 patients [6\%]) of statins with CYP3A4 inhibitors (10 with amiodarone, 1 with fluconazole and 1 with verapamil) and 4 pDDIs of statins with colchicine, a CYP3A4 substrate. 


\section{pDDIs' outcome}

Of the 17 pDDIs $(20 \%$ of the patients on statin before admission) identified in the therapy before admission that could lead to muscular disorders, 2 resulted in myalgia (Table 3). A 52 years-old male patient on atorvastatin and feno- fibrate reported muscle pain in the lower limbs and hips with moderate to severe intensity enhanced by the physical activity. Likewise, another 57 yearsold male patient with renal failure, taking simvastatin and colchicine, reported mild muscle pain in the lower and upper limbs. The CK levels were not assessed for either of the 2 patients.

Table 2

Laboratory values of the patients on statin therapy (at admission)

\begin{tabular}{lccc}
\hline \multicolumn{1}{c}{ Parameter, median (IQR) } & $\begin{array}{c}\text { Patients with no pDDIs } \\
(\mathbf{n = 7 9 )}\end{array}$ & $\begin{array}{c}\text { Patients with pDDIs } \\
(\mathbf{n}=\mathbf{3 0})\end{array}$ & p-value \\
\hline Creatinine $(\mathrm{mg} / \mathrm{dl})$ & $1(0.87-1.29)$ & $1.34(1.03-1.45)$ & $\mathbf{0 . 0 1}$ \\
\hline Urea $(\mathrm{mg} / \mathrm{dl})$ & $37.4(25.90-48.10)$ & $49.3(42.45-56.90)$ & $\mathbf{0 . 0 0 5}$ \\
\hline Triglycerides $(\mathrm{mg} / \mathrm{dl})$ & $115(77.00-160.00)$ & $117(87.00-158.00)$ & 0.29 \\
\hline $\begin{array}{l}\text { Aspartate aminotransferase } \\
\text { (IU/L) }\end{array}$ & $22(18.00-27.75)$ & $19(15.00-26.00)$ & 0.14 \\
\hline Alanine aminotransferase (IU/L) & $20(13.00-28.00)$ & $16(10.00-26.00)$ & 0.11 \\
\hline Gamma glutamyl transferase (U/L) & $30(19.00-41.00)$ & $36.5(26.25-53.50)$ & $\mathbf{0 . 0 4}$ \\
\hline CK (U/L) & $79(58.00-117.00)$ & $68(50.75-90.25)$ & 0.30 \\
\hline $\mathrm{n}=$ number of patients with available results; pDDIs $=$ potential drug-drug interactions of statins; IQR $=$ interquartile range \\
\hline
\end{tabular}

Table 3

Potential DDIs and clinical outcome in hospitalized patients' therapy before/during hospitalization

\begin{tabular}{|c|c|c|c|c|c|}
\hline Statin & Interacting drug & $\begin{array}{l}\text { Before admission, } \\
\text { no. of cases }\end{array}$ & $\begin{array}{c}\text { During } \\
\text { hospitalization } \\
\text { no. of cases }\end{array}$ & Severity & $\begin{array}{c}\text { Clinical } \\
\text { outcome* }\end{array}$ \\
\hline \multirow[t]{5}{*}{ Atorvastatin } & Digoxin & 3 & 1 & Moderate & - \\
\hline & Amiodarone & 2 & 1 & Moderate & - \\
\hline & Colchicine & 2 & 1 & Major & - \\
\hline & Fenofibrate & 1 & 1 & Major & Myalgia \\
\hline & Carbamazepine & 2 & - & Major & - \\
\hline \multirow[t]{2}{*}{ Lovastatin } & Verapamil & 1 & - & Major & - \\
\hline & Carbamazepine & 1 & - & Moderate & - \\
\hline \multirow[t]{3}{*}{ Rosuvastatin } & Acenocoumarol & 4 & - & Moderate & - \\
\hline & Amiodarone & 3 & 2 & Moderate & - \\
\hline & Fenofibrate & 3 & - & Major & - \\
\hline \multirow[t]{5}{*}{ Simvastatin } & Amlodipine & 2 & - & Major & - \\
\hline & Amiodarone & 1 & 1 & Moderate & - \\
\hline & Fluconazole & - & 1 & Moderate & - \\
\hline & Colchicine & 1 & - & Major & Myalgia \\
\hline & Fenofibrate & 1 & - & Major & - \\
\hline Total no of pDDIs & & 27 & 8 & & \\
\hline
\end{tabular}

\section{DISCUSSION}

The risk factors for statin-induced muscular disorders include, among others, the associations of drugs that may interact with the statins resulting in elevated serum concentration of the statins $[10,14-$ 18].

The total number of pDDIs found in our patients was higher before admission (27 pDDIs) compared to the therapy during hospitalization ( 8 pDDIs). This could be due to more cautious prescribing during hospitalization on the one hand, and probably due to the prescription of drugs by different prescribers for the same patient in ambulatory settings, on the other hand. The issue of different prescribers for one patient is expected to be attenuated once the health cards, comprising information on patient's disorders and therapy, will be fully functional and will allow the easy access to patient's therapy for each prescriber.

We found that $21(20 \%)$ of the patients had been prescribed statins together with drugs that may increase the risk for muscular disorders (corresponding to 24 pDDIs as 3 patients had pDDIs 
both before and during hospitalization). Of these, only 1 patient was prescribed an interacting drug for short term usage (CYP3A4 inhibitor, fluconazole), the rest of the patients being on long term therapy with both the statin and the interacting drug.

With regard to the CYP3A4 inhibitors association, $7(6 \%)$ of the patients had been prescribed CYP3A4 metabolized statins (atorvastatin, lovastatin, simvastatin) together with CYP3A4 inhibitors and 5 patients were prescribed rosuvastatin (CYP2C9 metabolization) together with amiodarone (CYP3A4 and CYP2C9 inhibitor). In addition, 4 patients had been prescribed simvastatin or atorvastatin with colchicine (a CYP3A4 substrate). A study performed in the Norwegian prescription database found that in 2006 up to $63 \%$ of the statin users were also prescribed one or more CYP3A4 inhibitors, depending on the statin type [25]. Another study from the United Kingdom performed in General Practice Research Database (GPRD) found that in primary care population approximately $30 \%$ of the patients that were prescribed a CYP3A4-metabolized statin had also been prescribed a concomitant CYP3A4 substrate/inhibitor [19].

Among the 17 patients with DDIs that could potentially lead to muscular effects, we found 2 $(12 \%)$ cases of myalgia. None of the 2 patients had been tested for CK, but we chose to consider these cases as it was already proven that most patients who develop significant muscle weakness and pain on statin therapy have normal CK levels [22]. None of the 2 patients were elderly (52 and 57 years-old), so they did not meet the age risk factor for statininduced muscular effects.

In one case colchicine and simvastatin were used concomitantly which may result in an increased risk of myopathy or rhabdomyolysis. The Summary of Product Characteristics for simvastatin containing drugs specifies that in case these drugs are both necessary in patient's therapy, the patient should be monitored for signs and symptoms of myopathy or rhabdomyolysis. In our case, the patient on simvastatin $(20 \mathrm{mg} /$ day $)$ and colchicine $(1 \mathrm{mg} /$ day) had additional risk factors for myopathy: type 2 diabetes, mild renal insufficiency and possibly thyroid dysfunction (thyroid nodules, but no laboratory data for the thyroid function available) that could contribute to the muscle pain.

The other patient with myalgia was on fenofibrate $160 \mathrm{mg} /$ day and atorvastatin $20 \mathrm{mg} /$ day. The association of the statins with fenofibrate does not affect the plasma concentration of statins but can also lead to myopathy and rhabdomyolysis through pharmacodynamic additive effects. The association is efficiently used for the treatment of mixed hyperlipidemia by improving the lipids' profile, but it is accompanied with a higher risk for myopathy. Drug interactions of statins and fibrates occur frequently, resulting in a substantial number of myopathy and rhabdomyolysis reports [26]. In addition to the association of the 2 drugs, our patient had impaired liver function with transaminase values elevated almost twice the upper normal limit. It was shown that fibrates may impair liver function independently; therefore the combination statin-fibrates should not be given to patients with impaired liver function [26].

We also identified other drugs that could interact with statins resulting in clinical outcomes different than muscular effects. We had 4 pDDIs of digoxin used together with atorvastatin which could lead to an increase in plasma concentration of digoxin (up to 20\%) and consequently digoxin's adverse reactions [27], 4 pDDIs of acenocoumarol and rosuvastatin which may result in increase of international normalized ratio (INR) and increased risk of bleeding [28] and 3 pDDIs of carbamazepine and atorvastatin ( 2 cases) and lovastatin ( 1 case) that could result in decreased exposure to the statin and consequently a lower efficacy. None of these pDDIs had clinical outcome.

\section{Limitations}

One of the limitations is the fact that, our study being of small scale, the results cannot be extrapolated to other medical units as healthcare environments may vary a lot between hospitals and countries. Another limitation could be the possible incomplete medical record documentation at the admission of the patient, which may lead to underestimation of the number of potential DDIs. Partially we countervailed this shortcoming by interviewing each patient regarding all the medicines used before hospitalization. Evaluation of CK levels was not performed in all suspected cases, restricting the characterization of the 2 cases of myalgia.

\section{CONCLUSIONS}

The prevalence of statins' pDDIs was high in our study, mostly in the therapy before admission, with only a small number of pDDIs resulting in clinical outcome. The outcome of the DDIs was myalgia, of mild and moderate-to-severe intensity, respectively. Further prospective research on a 
larger number of patients would allow a more accurate estimation of the pDDIs' prevalence and a causal association between statins' pDDIs and muscular effects.

Acknowledgments. This paper was published under the frame of European Social Found, Human Resources Development Operationl Programme 2007-2013, project no. POSDRU/159/1.5/136893.
Data from this paper was previously presented as poster at the $49^{\text {th }}$ Annual Scientific Meeting of the European Society for Clinical Investigation, $27^{\text {th }}-30^{\text {th }}$ May, Cluj-Napoca, Romania (abstract number S33).

We want to thank master students Adela Adamescu and Flavia Cuibus for their involvement in the study.

Conflict of interest: Authors have no conflicts of interests to declare.

Introducere. Asocierea unor medicamente care pot interacționa cu statinele rezultând în concentrații serice crescute ale statinelor reprezintă un factor de risc important pentru afectările musculare determinate de statine. Obiectivul studiului a fost de a determina prevalența acestor asocieri la pacienții spitalizați, cu statine in terapia dinainte de internare sau din timpul spitalizării şi de a determina frecvența cu care acestea sunt asociate cu afectare musculară.

Metode. Acest studiu prospectiv observațional a inclus pacienții cu statine in terapie din 2 secții de medicină internă. Date referitoare la caracteristicile pacienților, co-morbiditățile şi terapia medicamentoasă au fost colectate din fişa pacientului şi interviul cu acesta. Terapia a fost evaluată pentru interacțiuni medicamentoase potențiale (IMp) cu programul informatic Thomson Micromedex Drug Interactions. Fiecare pacient cu statină în terapia dinainte de internare a fost intervievat suplimentar pentru identificarea eventualelor afectări musculare.

Rezultate. In terapia celor 109 pacienți tratați cu statine am identificat 35 de IMp la $30(27.5 \%)$ de pacienți, majoritatea în terapia dinainte de internare $(n=27)$. Severitatea IMp a fost moderată $(n=20)$ şi majoră $(n=15)$, iar 24 IMp vizau sistemul muscular. Medicamentele cele mai frecvent implicate în IMp ale statinelor au fost amiodarona şi fenofibratul. Doi dintre pacienții cu IMp au raportat dureri musculare, ambii având factori de risc suplimentari pentru afectarea musculară determinată de statine.

Concluzie. Prevalența IMp ale statinelor a fost mare în studiul nostru, indeosebi în terapia dinainte de internare. Un număr mic de IMp au fost asociate cu afectare musculară.

Correspondence to: Camelia Bucşa Drug Information Research Center,

"Iuliu Hatieganu" University of Medicine and Pharmacy, Cluj-Napoca, Romania

$6^{\text {th }}$ Pasteur Street, 400349, Cluj-Napoca, Romania

E-mail: cfarah@umfcluj.ro, tel +40745608008

\section{REFERENCES}

1. WALLEY T, FOLINO-GALLO P, STEPHENS P, VAN GANSE E. Trends in prescribing utilization of statins and other lipid lowering drugs across Europe 1997-2003. Br J Clin Pharmacol 2005; 60:543-51.

2. KILDEMOES HW, STØVRING H, ANDERSEN M. Driving forces behind increasing cardiovascular drug utilization: a dynamic pharmacoepidemiological model. Br J Clin Pharmacol 2008; 66:885-95.

3. WALLEY T, FOLINO-GALLO P, SCHWABE U, VAN GANSE E. EUROMEDSTAT GROUP. Variations and increase in use of statins across Europe: data from administrative databases. BMJ 2004; 328:385-6.

4. TEELING M, BENNETT K, FEELY J. The influence of guidelines on the use of statins: analysis of prescribing trends 19982002. Br J Clin Pharmacol 2005; 59:227-32.

5. DUBOIS RW, DEAN BB. Evolution of clinical practice guidelines: evidence supporting expanded use of medicines. Dis Manag 2006; 9:210-23.

6. PETURSSON H1, GETZ L, SIGURDSSON JA, HETLEVIK I. Can individuals with a significant risk for cardiovascular disease be adequately identified by combination of several risk factors? Modelling study based on the Norwegian HUNT 2 population. J Eval Clin Pract 2009; 15:103-9.

7. BRUGTS JJ1, DECKERS JW. Statin prescription in men and women at cardiovascular risk: to whom and when? Curr Opin Cardiol 2010; 25:484-9. 
8. ARMITAGE J. The safety of statins in clinical practice. Lancet 2007; 370:1781-90.

9. BRUCKERT E, HAYEM G, DEJAGER S, YAU C, BÉGAUD B. Mild to moderate muscular symptoms with high-dosage statin therapy in hyperlipidemic patient - -the PRIMO study. Cardiovasc Drugs Ther 2005; 19:403-14.

10. PASTERNAK RC, SMITH SC JR, BAIREY-MERZ CN, GRUNDY SM, CLEEMAN JI, LENFANT C. ACC/AHA/NHLBI clinical advisory on the use and safety of statins. J Am Coll Cardiol 2002; 40:567-72.

11. GRAHAM DJ, STAFFA JA, SHATIN D, ANDRADE SE, SCHECH SD, LA GRENADE L, et al. Incidence of hospitalized rhabdomyolysis in patients treated with lipid-lowering drugs. JAMA 2004; 292:2585-90.

12. LAW M, RUDNICKA AR. Statin safety: a systematic review. Am J Cardiol 2006; 97:52C-60C.

13. JOY TR, HEGELE RA. Narrative review: statin-related myopathy. Ann Intern Med 2009; 150:858-68.

14. LÖFBERG M, JÄNKÄLÄ H, PAETAU A, HÄRKÖNEN M, SOMER H. Metabolic causes of recurrent rhabdomyolysis. Acta Neurol Scand 1998; 98:268-75.

15. ANTONS KA, WILLIAMS CD, BAKER SK, PHILLIPS PS. Clinical perspectives of statin induced rhabdomyolysis. Am J Med 2006; 119:400-409.

16. JACOBSON TA. Toward "pain-free" statin prescribing: clinical algorithm for diagnosis and management of myalgia. Mayo Clin Proc 2008; 83:687-700.

17. TAHA TA, DE MOOR CH, BARRETT DA, GERSHKOVICH P. Translational insight into statin-induced muscle toxicity: from cell-culture to clinical studies. Transl Res 2014; 164:85-109.

18. CHATZIZISIS YS1, KOSKINAS KC, MISIRLI G, VAKLAVAS C, HATZITOLIOS A, GIANNOGLOU GD. Risk factors and drug interactions predisposing to statin-induced myopathy: implications for risk assessment, prevention and treatment.Drug Saf 2010; 33:171-87.

19. BAKHAI A, RIGNEY U, HOLLIS S, EMMAS C. Co-administration of statins with cytochrome P450 3 A4 inhibitors in a UK primary care population. Pharmacoepidemiol Drug Saf 2012; 21:485-493.

20. ITO MK, MAKI KC, BRINTON EA, COHEN JD, JACOBSON TA. Muscle symptoms in statin users, associations with cytochrome P450, and membrane transporter inhibitor use: a subanalysis of the USAGE study. J Clin Lipidol 2014; 8:69-76.

21. BALLANTYNE CM, CORSINI A, DAVIDSON MH, HOLDAAS H, JACOBSON TA, LEITERSDORF E, et al. Risk for myopathy with statin therapy in high-risk patients. Arch Intern Med 2003; 163:553-64.

22. FERNANDEZ G, SPATZ E, JABLECKI C, PHILLIPS PS. Statin myopathy: a common dilemma not reflected in clinical trials. Clev Clin J Med 2011; 78:393-403.

23. Micromedex ${ }^{\circledR} 2.0$, (electronic version). Truven Health Analytics, Greenwood Village, Colorado, USA. Available at: http:// www.micromedexsolutions.com/ (cited: March/31/2015).

24. THE R DEVELOPMENT CORE TEAM. A language and environment for statistical computing. R Foundation for Statistical Computing; 2015. Available at http://www.R-project.org.

25. DEVOLD HM, MOLDEN E, S SKURTVEIT, FURU K. Co-medication of statins and CYP3A4 inhibitors before and after introduction of new reimbursement policy. BR J Clin Pharmacol 2009; 2:234-41.

26. OMAR MA1, WILSON JP, COX TS. Rhabdomyolysis and HMG-CoA reductase inhibitors. Ann Pharmacother 2001; 35:1096-107.

27. BOYD RA, STERN RH, STEWART BH, WU X, REYNER EL, ZEGARAC EA, et al. Atorvastatin coadministration may increase digoxin concentrations by inhibition of intestinal p-glycoprotein-mediated secretion. J Clin Pharmacol 2000; 40:91-8.

28. BARRY M. Rosuvastatin-warfarin drug interaction. Lancet 2004; 363:328.

Received June 19, 2015 